\title{
Rouhani's and Obama's Persian New Year messages: A systemic functional grammar perspective
}

\author{
Amin Karimnia ${ }^{1}$ \& Shidak Rahbarian ${ }^{2}$ \\ ${ }^{1}$ Fasa Branch, Islamic Azad University, Iran \\ ${ }^{2}$ Central Tehran Branch, Islamic Azad University, Iran
}

\begin{abstract}
This study investigated Nowruz (Persian New Year) messages by Presidents Hassan Rouhani and Barack Obama in March 2016. The study critically analyzed the discourse of these two presidential messages and uncovered the hidden aspects of their ideologies, policies, and background worldviews. In doing so, an integrated version of Halliday's systemic functional grammar (SFG) and critical discourse analysis (CDA) was used. The analysis of data included various linguistic dimensions (e.g. processes, modality, transitivity) of the messages and their statistics. Although results suggested that Obama intended to build a more intimate situation, both presidents tried to inspire a spirit of action, development and effort in their respective governments. The messages did not reveal considerable thematic differences, except some discoursal religious features expressed in Rouhani's message.
\end{abstract}

Keywords: critical discourse analysis; political relations; Iran; USA; systemic functional grammar; New Year.

\section{Introduction}

Language represents one of the indispensable dimensions of human life. Many defining features of humanity, including rationality, are thought to directly depend on language. The study of language and discourse, then, constitutes one of the most essential sources of knowledge in human personal and social life. Titscher et al. (2000: 25) believe discourse is a very broad term and they point out that "the notion of discourse, in both the popular and the philosophical use of the term, integrates a whole palette of different meanings that often seem to be contradictory or mutually exclusive". Studies concerned with discourse analysis incorporate linguistics, 
sociology, philosophy, anthropology, and psychology. According to Fairclough (1989), discourse is a broader notion than text because it not only refers to language, but also to social interactions in socially specific situations.

Renkema (2009) contends that Discourse Analysis is a discipline which analyzes the relationship between form and function in verbal communication. According to Fairclough (1989 as cited in Bayram, 2010) the term refers to "the whole process of interaction of which a text is just a part" (Fairclough, 1989: 24). Discourse involves expressing oneself through words, asserting power and knowledge. The speaker expresses his/her ideological content in texts through linguistic forms. "Texts are selected and organized syntactic forms whose "content-structure" reflect the ideological organization of a particular area of social life" (Dellinger, 1995 as cited in Bayram, 2010: 27).

As Brown and Yule (1983) state, the term "discourse analysis" covers a wide range of meanings, activities and disciplines from sociolinguistics, psycholinguistics and philosophical linguistics to computational linguistics. They further point out that discourse analysis cannot be "restricted to the description of linguistic forms independent of the purpose or functions which those forms are designed to serve in human affairs" (Brown and Yule, 1983: 1). While some linguists may concentrate on determining the formal features of language, a discourse analyst is committed to an investigation of what language is used for. A particularly interesting branch of discourse studies is called Critical Discourse Analysis (CDA). As Fairclough and Fairclough (2013) observe, power is an ever-present concern in CDA. Wodak (2001:11) believes that "power is signaled not only by grammatical forms within a text, but also by a person's control of a social occasion by means of the genre of a text".

CDA proposes a mutual interaction between language and power relations, as well as between superiority and ideology. Ideological structures always serve power relations in a society and, as the critical discourse analysts argue, power is imposed via force majeure (force and weapon) or via language and specially oriented discourses. Language can be even more powerful if it is used effectively. An effective application of language rests on ideological structures which are indirectly communicated to recipients (Karimnia \& Barbareh, 2017; Tavakkoli \& Karimnia, 2017; Yarmohammadi, 2007). To achieve this goal, producers of discourse integrate several layers and levels of meaning into their output. The surface layers exhibit linguistic structures, although the layers beneath conceal ideologies and power relations. Dealing with these layers is the task of critical analysts.

This research aims to analyze the New Year (Nowruz) messages by two Presidents from two countries with a history of tension and conflict over the 
past decades: Iran and the USA. To accomplish these goals, the study relies on Halliday's linguistics. By extracting and categorizing the micro- and macro-structures of the Presidents' messages, the study seeks to disclose the ideologies and worldviews behind each message. Specifically, this study explores and discusses Nowruz messages from March, 2016, delivered by Hassan Rouhani and Barack Hussein Obama. The messages were meant to congratulate Iranian people on the occasion of the Persian New Year. Although this kind of message is common in Iran, it has also become sent in the USA since Obama took office. In fact, Obama showed a more closer relationship with Iran, and an open policy.

In sum, the aim of this study is to determine the frequency and purpose of different devices used in these messages, along with their background worldviews and the relationship between language, ideology and power. In doing so, the study relies on critical discourse analysis (CDA) from Halliday's systemic functional grammar (SFG). The analysis tries to uncover the hidden aspects of the speakers' ideologies, policies and background thoughts by scrutinizing their linguistic devices and features. Simply, it seeks to identify and analyze dominant micro-structures (linguistic features) and macro-structures (extra-linguistic features) in Rouhani's and Obama's Nowruz messages according to the SFG-based CDA.

\section{Background}

SFG was introduced by the linguistic Halliday (1994) and is considered to be one of the most important substructures of CDA and other theories in pragmatics. According to Renkema (2009), there is a strong interdisciplinary bond between SFG and CDA. Developed by Halliday, SFG involves a sociosemiotic approach to language. It is composed of two major components: systemic grammar and functional grammar. The systemic part is viewed as "a network of systems or interrelated sets of options for making meaning" (Halliday 1994: 23), and it aims to explain the internal relations in language as a network consisting of subsystems from which language users make choices. The functional part, however, deals with language as a means of social interaction, resting on the assumption that a language system and the forms in it are inescapably determined by the functions which they serve (Zhuanglin, 1988).

Halliday (1970) argues that language is inherently functional. In his early papers on English grammar, he referred to the functional components of language as generalized uses of language. Since they seem to determine the nature of the language system, they need to be incorporated into our account of that system. Furthermore, Halliday observes that this functional organiza- 
tion of language determines the form taken by grammatical structure. He refers to these functions of language as meta-functions (Halliday, 1970). There are three general functions: ideational, interpersonal and textual. In the following sub-sections, each of these major functions is separately explained in further detail.

\subsection{Ideational meta-function}

The ideational meta-function involves an interpretation of human experiences by which we make sense of reality. It is divided into the logical and the experiential meta-functions. The former refers to the grammatical resources for building up grammatical units into complexes; the experiential meta-function, however, includes grammatical resources involved in construing the flux of experience through the unit of the clause (Halliday \& Matthiessen, 2004 :61). Our experience of reality is captured in terms of processes (e.g. becoming, meaning, sensing, doing, being, and happening). These processes constitute the transitivity system of language, which belongs to the experiential meta-function.

In transitivity analysis, we explore how language shapes our experience of the world around us. The transitivity system is composed of six processes (Saragih, 2010):

(1) Material processes: They demonstrate events or activities which happen in the real world. Halliday (1994) asserts that material processes are in fact processes of "doing". Clauses with a material process necessarily have a process (doing), a participant (doer), and an entity to which the process is directed or extended.

(2) Mental processes: They refer to verbs indicating perception, affection, desire and cognition (Saragih, 2010). Mental processes enable language users to express tastes, thoughts, and opinions, all of which contribute to the identification of their definition of reality. This process can be realized via the use of verbs such as hear, think, see, like, want, enjoy, repel, and admire.

(3) Verbal processes: Oral production is certainly a type of communication mechanism, and to some extent it would be reasonable to treat it as a material process. Moreover, verbal processes include some features of mental processes. Saragih (2010) believes that verbal processes indicate activities related to information, namely asking, commanding, saying, and offering.

(4) Relational processes: They occur inside and outside of a human being. Relational processes are realized via verb "to be" or copular verbs (seem, appear, become) or by verbs such as own, have, and possess. 
(5) Behavioral processes: They are hybrid processes that incorporate material and mental mechanisms. Typically, there is only one participant who is "behaving", i.e., the human who is a conscious being.

(6) Existential processes: These processes imply that something happens or exists. Saragih (2010) asserts that they share features of relational process in the sense that the common verb is "to be" (am, is, are, have, has, was, were, etc.), along with some other verbs such as come, go, exist, arise, remain, happen, and occur. Existential processes are signaled by the Subject "there".

\subsection{Interpersonal meta-function}

The interpersonal meta-function encompasses text's aspects of tenor or interactivity (O'Halloran, 2006). According to Halliday (1970), the speaker uses language as an expression of his/her attitude through the use of positive or negative language options. According to Zhuanglin (1988), modality refers to the range between positive and negative extremes. Social distance determines how close the speakers are, e.g. how the use of nicknames indicates the degree to which they are intimate. Relative social status depends on equality in terms of power and background knowledge (Coffin, 2006). Finally, mood shows what the role a speaker selects and what the role they assign to the addressee considering intimacy and power (Zhuanglin, 1988).

\subsection{Textual meta-function}

Halliday (1970) explains that language makes links between itself and the situation; the discourse is possible because the speaker or writer can produce a text that listener or reader can recognize. The textual meta-function processes the internal organization and communicative nature of a text (O'Halloran, 2006). This dimension comprises textual interactivity with reference to dis-fluencies such as hesitators, pauses and repetitions, spontaneity, focusing on lexical density, grammatical complexity, coordination and cohesion (Coffin, 2006). SFG deals with all of these areas of meaning equally within the grammatical system itself.

\section{Methodology}

\subsection{Rationale for selecting the samples}

Hassan Rouhani, the leader of the Moderation and Development Party and the seventh president of Iran since the Islamic Revolution in 1979, sends Nowruz greetings, as it is popularly celebrated in Iran. Presidents give 
speeches at the beginning of each year and send New Year's greetings to the Iranian public. Issuing public messages at the beginning of each year have always been common in Iran, but it has become a practice in the U.S. since Obama took office. Obama, a member of the Democratic Party, the fortyfourth president of the USA, and the first African-American president in American history, started to issue messages and congratulations for the Persian New Year since he took office in 2009. However, issuing such messages, especially on a regular basis, was not common among US presidents in the past. In these messages, Obama usually wished for extended and peaceful relationships with Iran, despite bad relations the United States and Iran since the revolution. Both messages were delivered in March, 2016 (1st Farvardin, 1395).

These kinds of Nowruz speeches generally consist of salutations, congratulations for the New Year, hopes for a happy future relationships between the two countries. This year, however, the "Iran's nuclear program" was included in the message, which has recently been a worldwide issue. Among all the messages communicated over these years, the ones from March, 2016 were selected in this study. Because it was the first Nowruz after the implementations of Joint Comprehensive Plan of Action (JCPOA known as BARJAM in Persian) and this special juncture could help disclose how the presidents tried to represent their achievements and communicate them to their audiences.

These kinds of Nowruz speeches generally consist of salutations, congratulations for the New Year, hopes for a happy future and further relationship between the two countries, but this time, the message included an extra topic: "Iran's nuclear program", which has recently been a worldwide issue. Among all the messages communicated over these years, the ones delivered on March, 2016 were selected in this study, because it was the first Nowruz after the implementations of Joint Comprehensive Plan of Action (JCPOA known as BARJAM in Persian) and this special juncture could help disclose how the presidents tried to represent their achievements and communicate them to their audiences.

\subsection{Procedure}

To have an accurate and statistically analyzable profile of both of presidential messages, it was necessary to transcribe them. Then, the words, sentences, and paragraphs were counted. By calculating the mean of the length of the sentences, the degree of difficulty and complexity of the words and sentences were also investigated. Following that, a CDA-based analysis was conducted through the strategies of SFG proposed by Halliday (1994), in order to categorize and sort the structures and devices applied. A qualitative 
analysis of the messages was provided and the preferences, interests, and hidden policies were scrutinized.

These items were investigated through a transitivity analysis. The ideational function was utilized in this part. Transitivity is a kind of semantic system which analyzes human experiences into sets of process types. These processes, as mentioned earlier, are divided into 6 types, based on which the presidential messages were categorized. Then the types of the processes were also sorted and tabulated, and the percentages and frequencies for each message were calculated.

The second major analysis section of this paper scrutinized the modality of the messages. This section included the speakers' attitudes and opinions towards the audience (listeners or readers). The modals were then categorized into degrees of politeness (see Table 3). Another subcategory of modality analysis dealt with the tense of verbs; according to Halliday (1994), the primary tenses are the past, the present, and the future. Finally, the tenses were counted and their percentages and statistics were also calculated (see Table 4). The use of pronouns was discussed in the personal pronoun section (see section 3.3.4). Again, the frequencies of this micro-textual dimension were calculated and illustrated in a table (see Table 5). The last analysis part was concerned with the coherence evaluation of messages as unified textual productions which could be distinguished from a set of random sentences.

\subsection{Data analysis}

Obama's message consisted of 366 words, 53 sentences, and 19 paragraphs. It included simple words and simple sentences to make sure his audience would understand what he was talking about. Rouhani's message, on the other hand, was composed of 778 words, 56 sentences, and 21 paragraphs.

The length of an average sentence in Rouhani's and Obama's messages was 13 and 6.90 words per sentence, respectively. Thus, through the analysis of the statistical data, it can be concluded that contrary to Obama's language production, Rouhani's speech contained more complex and even larger sentences. Table 1 offers detailed information on the New Year messages.

Table 1. Statistics of sample messages.

\begin{tabular}{|l|c|c|}
\hline \multicolumn{1}{|c|}{ Statistical Items } & Obama's Speech & Rouhani's Speech \\
\hline Words & 366 & 778 \\
\hline Sentences & 53 & 56 \\
\hline Paragraphs & 19 & 21 \\
\hline Characters & 694 & 1010 \\
\hline Sentence Mean Length & 6.90 & 13 \\
\hline
\end{tabular}


As mentioned earlier, the analysis of data included various linguistic dimensions which are discussed in the following sections.

\subsubsection{Transitivity analysis}

In Halliday's (1994) theory, the ideational meta-function analyzes human experiences. Our experience of reality is captured in terms of processes (happening, doing, sensing, meaning, being, and becoming). These processes constitute the transitivity system of language (see section 2.1.):

Table 2. Transitivity in the sample messages.

\begin{tabular}{|c|c|c|c|c|c|c|c|}
\hline Speeches & Material & Relational & Mental & Verbal & Behavioral & Existential & Total \\
\cline { 1 - 7 } $\begin{array}{c}\text { Rouhani's } \\
\text { message }\end{array}$ & 40 & 7 & 5 & 10 & 2 & 6 & \multirow{2}{*}{70} \\
\cline { 1 - 6 } Percentages & $57.14 \%$ & $10 \%$ & $7.14 \%$ & $14.28 \%$ & $2.85 \%$ & $8.57 \%$ & \\
\hline $\begin{array}{c}\text { Obama's } \\
\text { message }\end{array}$ & 28 & 12 & 10 & 4 & 2 & 2 & \multirow{2}{*}{58} \\
\cline { 1 - 6 } Percentages & $48.27 \%$ & $20.68 \%$ & $17.24 \%$ & $6.89 \%$ & $3.44 \%$ & $3.44 \%$ & \\
\hline
\end{tabular}

As Table 2 illustrates, Rouhani's message contained more material $(57.14 \%)$ and verbal $(14.28 \%)$ processes than other possible processes. In Obama's speech comprised about $48 \%$ material and $21 \%$ relational processes more frequent than others.

\subsubsection{Modality analysis}

According to Halliday (1994), in the interpersonal meta-function, the speaker uses language as an expression of his/her attitude, which can be seen through the use of positive or negative statements. The speaker also needs to convey a degree of his/her intimacy with the addressee by using nicknames, less formal structures/words, everyday language, and talking about ordinary beliefs and notions. In this study, the speakers were presidents of two powerful nations, thus the role of power as an effective factor cannot be ignored. Framing a less formal speech could help speakers minimize the perceived distance between them and their audiences. "Mood" shows the role the speaker assumes and the role s/he assigns to the addressee according to the status of intimacy and power.

To enhance his intimacy with the Iranian audience, Obama employed the following Persian cultural items/ideas: (a) talking about Iranian's tradition of having sabzi-polo "a dish of rice and chopped herbs", usually served with fish at New Year's Eve), and naan-berenji "Persian rice-cookies"; (b) having a haft-seen set (a tabletop arrangement of seven symbolic items traditionally displayed on the occasion of the Persian New Year); and (c) reading the poem Spring by Fereydoon Moshiri (1927-2000), a prominent contemporary 
Persian poet. Even choosing the topic of the poem is a matter of discussion (as the Persian New Year occurs on the first day of spring). Table 3 shows the representation of all the devices and elements mentioned above in both messages:

Table 3. Politeness analysis of modals used in the messages.

\begin{tabular}{|l|c|c|c|c|c|c|c|c|}
\hline Messages & \multicolumn{2}{|c|}{$\begin{array}{c}\text { Total No. of } \\
\text { modals }\end{array}$} & \multicolumn{2}{c|}{$\begin{array}{c}\text { Slightly } \\
\text { polite }\end{array}$} & \multicolumn{2}{c|}{ Moderately polite } & \multicolumn{2}{c|}{$\begin{array}{c}\text { Extremely } \\
\text { polite }\end{array}$} \\
\hline $\begin{array}{l}\text { Rouhani's } \\
\text { message }\end{array}$ & 17 & $24.28 \%$ & 7 & $41.7 \%$ & 10 & $58.8 \%$ & 0 & $0 \%$ \\
\hline $\begin{array}{l}\text { Obama's } \\
\text { message }\end{array}$ & 20 & $24.48 \%$ & 6 & $30 \%$ & 14 & $70 \%$ & 0 & $0 \%$ \\
\hline
\end{tabular}

The degrees of politeness helped reveal the extent to which the speakers used formal or less formal verbs in their speeches. Using slightly polite modal verbs demonstrated a less formal speech, whereas including extremely polite modal verbs signaled a more formal speech. The data has shown that Rouhani used a total number of $24.28 \%$ modals in his speech, whereas in Obama's speech there were about $24.48 \%$ modals from among all the other verbs in his speech. As modal verbs are thought to convey speaker's attitudes and feeling to the listener, the data indicate that Obama made a more conscious attempt to communicate his modes, feelings and attitudes to the audience.

According to Table 3, modals with an average degree of politeness (such as can and will), which indicated the relative informality of the messages, were used more frequently than other types. Such modals constituted $70 \%$ of all the modals used in Obama's speech, in comparison to Rouhani's $58.8 \%$ Although slightly polite modal verbs were used less than the moderately polite ones, the former shaped $41 \%$ of the modals in Rouhani's message and $30 \%$ in Obama's. The speakers, however, did not use a single highly official polite modal verb (such as would and could). The most frequently used modal in Obama's speech was "will", which showed forward-looking approach and his positive perspective for continued relationships, which will be directly influenced by Iranian's future co-operations and observation of the terms of the Joint Comprehensive Plan of Action (JCPOA). The two most frequently used modals in Rouhani's speech were "can" and "will", which indicated Obama's hopes for future progresses and the Iranian governments' ability to provide people with change and progress in their lives.

\subsubsection{Tense}

Considering the notion of tense in the presidents' messages, the followings observations were made (see Table 4). Tense in general refers to three tenses, namely the past, the present, and the future. 
Table 4. Tense of sentences in the messages.

\begin{tabular}{|l|c|c|c|c|c|c|c|}
\hline Speeches & Total & \multicolumn{2}{|c|}{ Present } & \multicolumn{2}{|c|}{ Past } & \multicolumn{2}{|c|}{ Future } \\
\hline $\begin{array}{l}\text { Rouhani's } \\
\text { Speech }\end{array}$ & 70 & 44 & $62.85 \%$ & 22 & $31.42 \%$ & 4 & $5.71 \%$ \\
\hline $\begin{array}{l}\text { Obama's } \\
\text { Speech }\end{array}$ & 58 & 30 & $51.72 \%$ & 15 & $25.86 \%$ & 13 & $22.41 \%$ \\
\hline
\end{tabular}

According to Table 4, the simple present tense was dominantly used in both Rouhani's (62.58\%) and Obama's (51.72\%) speeches. The past tense, which constituted $31.42 \%$ of tenses in Rouhani's message and $25.86 \%$ in Obama's, was the second frequently applied time frame. The future tense, however, was used in $5.71 \%$ and $22.41 \%$ of the cases in Rouhani's and Obama's messages, respectively. As the presidential messages were directed toward a potential, future outlook, the present tense and the future tense were used to indicate progresses and plans and future actions. On the other hand, simple past and simple present were used by the president to express their previous actions and the results attached to them.

\subsubsection{Personal pronouns}

Regarding the application of pronouns, in particular personal pronouns, the following data were obtained (see Table 5). The use of pronouns in interpersonal meta-functions signaled the link between the speaker and listener. For example, the application of plural pronouns showed the intimacy between the speakers and the audience.

Table 5. Personal pronouns in the messages.

\begin{tabular}{|c|c|c|c|}
\hline \multicolumn{2}{|c|}{ Personal Pronouns } & $\begin{array}{c}\text { Rouhani's } \\
\text { speech }\end{array}$ & $\begin{array}{c}\text { Obama's } \\
\text { Speech }\end{array}$ \\
\hline \multirow{2}{*}{ 1st Person } & $\mathrm{I}$ & 9 & 7 \\
\cline { 2 - 4 } & $\mathrm{We}$ & 18 & 17 \\
\hline \multirow{3}{*}{ 2nd Person } & You & 0 & 9 \\
\cline { 2 - 4 } & $\mathrm{He}$ & 1 & 1 \\
\cline { 2 - 4 } & She & 0 & 0 \\
\cline { 2 - 4 } & It & 6 & 8 \\
\hline 3rd Person & They & 6 & 1 \\
\hline
\end{tabular}

Table 5 lists instances of "I" and "we" as the first-person pronouns, both singular and plural, which emphasized a unity between the government and people, contrary to ideology of other parties and critics such as the "Worried $^{1 "}$ party in Iran. Another significant aspect of Rouhani's message was

\footnotetext{
${ }^{1}$ The Worried consists of Iranian critics of the interim nuclear deal who held a conference called "We're Worried." The conference brought together conservative members of parliament, prominent political figures and the former head of Iran's Atomic Energy Organization to
} 
reference to the Supreme Leader, which highlighted the Revolution Leader's sole will and power in decision-making regarding the policies of Iran. His approval showed that government's (Rouhani's) activities are legitimate.

\subsubsection{Textual analysis}

Textual analysis of both presidents' messages revealed some other dimensions of the texts. This meta-function dealt with internal consistency and coherence of the texts and the logic of choosing topics one after another. In this part, a comparison was made between the form and structure of both messages.

Table 6. Textual coherence in Rouhani's and Obama's messages.

\begin{tabular}{|l|l|}
\hline \multicolumn{2}{|c|}{ Textual consistency } \\
\hline $\begin{array}{l}\text { Sequences of themes/topics in } \\
\text { Rouhani's message }\end{array}$ & $\begin{array}{l}\text { Sequences of themes/topics } \\
\text { in Obama's message }\end{array}$ \\
\hline $\begin{array}{l}\text { Starting the message with reference to } \\
\text { Allah }\end{array}$ & Greeting \\
\hline Greeting & $\begin{array}{l}\text { Congratulating people on the occasion } \\
\text { of Nowruz, referring to Iranian tradi- } \\
\text { tions and reading a poem by Moshiri }\end{array}$ \\
\hline $\begin{array}{l}\text { Congratulating people on the occa- } \\
\text { sion of Nowruz }\end{array}$ & $\begin{array}{l}\text { Reporting his efforts on expanding the } \\
\text { relationships with Iran }\end{array}$ \\
\hline $\begin{array}{l}\text { Reviewing activities in the previous } \\
\text { year }\end{array}$ & $\begin{array}{l}\text { Mentioning the present status of Iran } \\
\text { and the opportunities which will be } \\
\text { proposed by observing agreements }\end{array}$ \\
\hline $\begin{array}{l}\text { Addressing issues related to JCPOA } \\
\text { and its status }\end{array}$ & $\begin{array}{l}\text { Forecasting potential, future progresses } \\
\text { and expressing hopes for people's hap- } \\
\text { pier life conditions }\end{array}$ \\
\hline $\begin{array}{l}\text { Mentioning accomplishments and the } \\
\text { process through which international } \\
\text { agreements were reached }\end{array}$ & $\begin{array}{l}\text { Wishing a happy year and Nowruz } \\
\text { again }\end{array}$ \\
\hline $\begin{array}{l}\text { Expressing hopes and wishes for } \\
\text { development in people's everyday } \\
\text { lives and improvements via the im- } \\
\text { plementation of JCPOA 1-2 }\end{array}$ & $\begin{array}{l}\text { Resorting to God for his blessings and } \\
\text { sharing good wishes for next year }\end{array}$ \\
\hline
\end{tabular}

discuss why they believe Iran signed a bad deal. Shortly after, however, Iranians began posting their own comments and pictures online with the words "We're Worried," voicing their own concerns about the direction of the country and from that conference on the term became popular. Read more: http://www.al-monitor.com/pulse/originals/2014/05/iran-anti-nucleardeal-conference-backlash.html\#ixzz4iGqJ8ziD. 
In general, both presidents selected very similar topics, but there was one important difference in terms of religious beliefs. Obviously, in Rouhani's message there were strong religious indications as he (in)directly referred to Allah and the Fourteen Infallibles (the Prophet of Islam, his Daughter Fatima, and Twelve Imams) for about 23 times, which covered about $3 \%$ of his text.

\section{Discussion}

To have a clearer analysis of non-linguistic features of the two messages under study, material processes could prove to be more informative than other processes. Material processes involve material verbs or clauses such as "doing" (transitive verbs) and "happening" (intransitive verbs) (Saragih, 2010: 9). They generally refer to processes which represent materials or a visible, tangible change during an event in any environment (Halliday \& Matthiessen, 2004). The events are activated through energy input. These verbs or clauses construct and create our experiences of the world (Stojičić \& Momčilović, 2016: 3). This process was the most frequently used process in SFG. The doer of the action is called Actor and the receiver and/or the affected party is called Goal. Actor and Goal are comparable to the Subject and the Object in traditional grammar, respectively (Halliday \& Matthiessen, 2004).

Table 7. Frequency of Actors in material aspects of the messages.

\begin{tabular}{|l|l|}
\hline Speeches & Actors \\
\hline $\begin{array}{l}\text { Obama's } \\
\text { Speech }\end{array}$ & I \\
\cline { 2 - 2 } & $\begin{array}{l}\text { We/Our diplomats/our partners/the U.S. / } \\
\text { Our government, ... }\end{array}$ \\
\cline { 2 - 2 } & Fereydoon Moshiri \\
\cline { 2 - 2 } & It/ Iran/You/ Your family, ... \\
\hline Rouhani's & $\mathrm{I}$ \\
\cline { 2 - 2 } Speech & We/ Our nation \\
\cline { 2 - 2 } & The Supreme Leader (He) \\
\cline { 2 - 2 } & It/All nations/ the World/Sanctions \\
\hline
\end{tabular}

Table 7 shows how the process can be categorized in terms of Actors and Goals. The Actors in both messages were represented by items such as "I" and "We", and "Our people" or "Our nation". Such word choices would divide speakers, their parties and their followers from opposition groups (those who objected to increased relationships between Iran and the US). These relationships in Iran were both advocated and accepted by govern- 
ment and its followers, although the members of the other parties opposed to increased rapport between the countries. In Iran the conflict was intensified and the members of the opposition labeled themselves as the "Worried." They even held a conference called "The Large Conference of the Opponents to Agreement with America" on May 03, 2014 at the former US Embassy in Tehran (Karami, 2014). The main intention of this event was to express opposition to the nuclear deal in Geneva, which lead to the formation of "Worricism" as an independent party (Mahdavi, 2014). Another interesting point in Rouhani's speech was the mention of the Supreme Leader, who, according to the Iranian Constitution, has the ultimate authority. Needless to say, no action can be taken without Leader's consent and approval.

Compared to Obama's speech, Rouhani's production relied on more difficult words and more complex sentence structures as it was delivered in Persian. Furthermore, since the audience included people from different class and educational backgrounds, both Presidents tried to bridge the gap by rendering their language as comprehensive as possible. Yet, this effort was more evident in Obama's speech, as indicated by the analysis.

Moreover, mentioning his power and his satisfaction with governmental activities was a deliberately made choice on Rouhani's part and emphasized the fact that all the actions taken by government should be proved legitimate in advance. This fact would discredit the objections and disagreements expressed by the "Worried". The most frequently used verbs in Rouhani's message were make/build, finish, get to business, accompany, lead, and mark, which presented the action, motivation and energy that has government brought about in Iranians' lives and economy.

\section{Conclusion}

This study drew on an SFG-based CDA method to investigate various dimensions in Obama's and Rouhani's messages delivered on the occasion of the Persian New Year in March 2016. The findings of this research lead to a number of conclusions. First, Obama's use of simple words and sentences and his reference to Iranian traditions and cultural aspects showed his attempt to create an intimate setting with reduced distance between his government and Iranians. Second, material processes were more frequent than any other type in both speeches, revealing a spirit of action, energy and effort in both governments. Using this discoursal strategy, the Presidents emphasized a tangible change and improvement in their attempts, in contrast to previous governments. Third, speakers' modes and attitudes were indicated through the use of relatively polite modal verbs in order to create a less formal situation and connect with the audience. 
In addition, the analysis of pronouns revealed the presidents' sense of unity with their listeners, especially as they tried to distance themselves from the critics and opposition groups. The final section of the study dealt with the tenses used. The present tense was applied more than other tenses to express the present status of the country. The simple future tense was used to refer to possible future improvements and the promising world which could be built by mutual cooperation. Finally, the past tense was the second most frequent tense in the messages, as the speakers tried to express their activities in the past and highlight the changes they had directed. As far as the items reviewed above are concerned, the messages did not reveal any considerable differences, although one could observe religion-based differences on Rouhani's part.

The analysis of data in this paper represented the task of a critical discourse analyst who helps readers/listeners discover the similarities and differences between the texts with different ideological, social and religious differences. Unfolding and scrutinizing writers/speakers' intentions by analyzing the surface and underlying layers of their statements can guide people on how to interpret the functions and ideologies upon which texts are built.

As a practical implication, language users should be motivated to critically analyze spoken/written texts through CDA methodologies, especially those that rely on SFG. Language teachers, whether they teach a native language or a foreign one, can systematically apply CDA as an effective pedagogical tool in their career. Future studies, too, can investigate cases through the methodology used here, particularly within a comparative, political framework.

\section{References}

Bayram, Fatih (2010). Ideology and political discourse: A critical discourse analysis of Erdogan's political speech. Arecls 7: 23-40.

Brown, Gillian, George Yule (1983). Discourse Analysis. Cambridge: Cambridge University Press.

Coffin, Caroline (2006). English Grammar in Context: Book 3 - Getting Practical (Evaluating Everyday Texts). The Open University.

Fairclough, Isabela, Norman Fairclough (2013). Political Discourse Analysis: A Method for Advanced Students. London: Routledge.

Halliday, Michael (1994). Functional Grammar. London: Edward Arnold.

Halliday, Michael (1970). Functional diversity in language as seen from a consideration of modality and mood in English. Foundations of Language 6(3): 322-361.

Halliday, Michael, Christian Matthiessen (2004). An Introduction to Functional Grammar (3rd edn.). London: Edward Arnold. 
Karami, Arash (2014). 'We're Worried' conference against nuclear deal stirs backlash. http:/ / www.al-monitor.com/pulse/originals/2014/05/iran-anti-nucleardeal-conference-backlash.html. (last access 01/05/2016).

Karimnia, Amin, Leila Barbareh (2017). Moves, poetic types, poetic schemes, and cultural themes in Iranian obituaries. Journal of Multicultural Discourses 12: 290-305.

Mahdavi, Seyedamir Hossein (2014). Worried or valiant? The dialectic between Iran's nuclear negotiations and its domestic politics. Middle East Brief, Brandeis University, Crown Center for Middle East Studies 8: 1-8.

O'Halloran, Kieran (2006). English Grammar in Context, Book 2: Getting Inside English. Milton Keynes: The Open University.

Renkema, Jan (2009). Discourse, of Course: An Overview of Research in Discourse Studies. Amsterdam: John Benjamins.

Saragih, Amrin (2010). Introducing Systemic Functional Grammar of English. Medan: FBS UNIMED

Stojičić, Violeta, Nikoleta Momčilović (2016). Verbal derivatives and process types in transitivity configurations of English and German clauses. Linguistics and Literature 14(1): 15-24.

Tavakoli, Mahboobeh, Amin Karimnia (2017). Dominant and gender-specific tendencies in the use of discourse markers: Insights from EFL learners. World Journal of English Language 7(2): 1-9.

Titscher, Stefan, Michael Meyer, Ruth Wodak, Eva Vetter (2000). Methods of Text and Discourse Analysis: In Search of Meaning. UK: Sage Publications.

Wodak, Ruth. (2001). The discourse-historical approach. Wodak, Ruth, Michael Mayer, eds. Methods of Critical Discourse Analysis. London: Sage, 63-94.

Yarmohammadi, Lotfollah (2007). ?ertebatat ?æz mænzær-e gofteman shenasi-ye ?enteqadi (Communications from Critical Discourse Perspective). Tehran: Hermes.

Zhuanglin, $\mathrm{Hu}$ (1988). A Course of Linguistics. Beijing: Peking University Press.

\section{Authors' addresses:}

Amin Karimnia

Fasa Branch, Islamic Azad University, Iran

e-mail: aminkarimnia@yahoo.com

Shidak Rahbarian

Central Tehran Branch, Islamic Azad University, Iran

e-mail: rahbarian63@gmail.com

Received: November 30, 2017

Accepted for publication: January 16, 2018 